\title{
Deviations of phraseological units in individually-author's picture of the world
}

\author{
N. D. Nehrych \\ Yuriy Fedkovy ch Chernivtsi National University \\ Corresponding author. E-mail: natalia.negrych@ gmail.com
}

Paper received 28.10.17; Revised 02.11.17; Accepted for publication 05.11.17.

https://doi.org/10.31174/SEND-PH2017-145V41-08

\begin{abstract}
The paper is focused on idioms of English language in individually-author's picture of the world in the novels of British writer of postmodern literature Jasper Fforde. Language world picture reflects and interprets reality by way of language means and phraseological units take an imp ortant place among them. Author's consciousness is inevitably connected with individually -author's picture of the world. Individually-author's picture of the world is a fragment of language world picture in the light of author's outlook, worldview and percept ion of the world.
\end{abstract}

Keywords: Idiom, phraseological unit, individually-author's picture of the world, language world picture, transformation, postmodern literature.

Formation of a research problem and its significance. Phraseological units are quite complex linguis tic configurations. They are an important part of the colloquial language. Even if people are not aware of it, phraseologisms are used very frequently in everyday speech and very often, when people have a convers ation, they can be used without noticing them. Such phrases range on a scale from the less complex to phrases which might be regarded as proverbs rather than phraseological units or idioms. What they all have in common, is that their meanings are not deducible from the ordinary meanings of their components by the usual rules of compositionalsemantics. These constructions may change their conventional appearance: parts of their conventional formal and semantic substructures can be highlighted with others changing or fading away. Such exploitations happen and are very noticeable in text, but they are not the dominant type. Analysis of the research into this problem. For this reason idiomatic expressions have been object of several studies among linguis ts for the last decades: $\mathrm{H}$. Burger et. al (1982), H. Burger (1998a), R. Moon (1998), D. Dobrovol'skij, E. Piirainen (2001), M. Everaert (2005), A. Langlotz (2007), P. Skandera (2007), A. Sabban (1998) and others.

The goal and the specific tasks of the article. The aim of the article is to identify types of phraseological variation in postmodernist discourse of Jasper Fforde's novels. We're going to use terms phraseological unit (PU), idiom or idiomatic expression defining them like most linguists do: polylexemic expression whose meaning cannot be deduced from the meaning of its parts.

Statement regarding the basic material of the research and the justification of the results obtained. Recent years has seen rising interest in postmodernist literature, fiction of Postmodern in particular as a kind of contemporary fiction. Fiction in the 21st century, it might be argued, exists at a time when everything has already been said, written, invented, discussed, destroyed and reconstructed again - in the aftermath of modernism and the subsequent reconsideration of its experiments within postmodernism. Interest in the how (the telling, the process of narration), rather than the what (the story itself), is one of the general symptoms of this era [2]. Newness was the leading value of literary modernism, whereas postmodern literature obsessively revisits and rereads its own past. Narrative self-consciousness has always been a feature of the novel, but it has become more so in contemporary literature. This could either be a reflection of a wider cultural self-consciousness which can be pointed to in film, architecture, fashion and the TV game show or it could be a more specific response to developments in the theory of language and literature which make it more difficult to write a novel that does not reflect on its own role in the construction of reality [4]. English works of Postmodern are rhizomatous texts that have no center and are nonlinear form of postmodernist writings, nonlinear model of literature that destroys any hierarchy and order. Genre models of such works create special conditions for various versions of text reading. Rejecting early specified direction of reading, in particular, facilitates overcoming of contradictions between linearity of writing and nonlinearity of thinking [1]. Jasper Fforde, as British novelist writing in the field of postmodern literature characterized by heavy reliance on techniques like fragmentation, paradox, and questionable narrators, with the novels which we here dealt with The Eyre Affair (2002), Lost in a Good Book (2003), The Well of Lost Plots (2004),Something Rotten (2005), First Among Sequels (2007), One of Our Thursdays is Missing (2011), The Woman Who Died a Lot (2012) represent symbiosis of alternative history and comic fantasy. As an author of postmodernist literature J. Fforde employs two basic plot devices. One is the "Alternative Universe" scenario. The other is that the world of fiction and the real world ("outland") run into each other.

Idioms are pervasive in all styles of language use. That is why one might as sert that in literature of postmodernist period which is characterized by its originality as well as in novels of such imaginative postmodernist author as J. Fforde idioms might appear not only in dictionary forms but deviate from them considerably. Linguis ts notice that there are hardly any types of variation of an idiomatic expression, which would not be feasible given an appropriate context [3]. For purposes of analysis it is essential not only to have a clear idea of the concept of the phraseological unit (PU) or id iom (we use both terms) as a separate entity, but also to establish terms for denoting various types of form of the PU and to reflect their meaning and function. A. Naciscione proposes the term the base form in the English language to indicate the form of the PU to which other forms of the PU can be related and with which they can be compared [7]. In practice, the base form is the dictionary form and meaning, recorded as the head phrase. In its base form the PU is a static out-ofcontext formation which does not depend on discourse. Syntactically the base formnever exceeds the boundaries of one sentence. Some PUs constitute a full sentence, including compound or complex sentences, but they never go beyond the limits of a sentence in their base formor core use. In text, PUs often appear in their standard form and meaning. A. Naciscione introduces the term core use to denote the basic, most common, essential form and meaning which is the in- 
variable of the PU available to a language user. In many ways core use resembles the base form. We exploit the base form which is the dictionary form to distinguish PUs with devations. In linguistic literature very often terms transformation and variation are used to denote the same thing. To categorize the idioms with variations we use the taxonomy offered by R. Moon [6]. The linguist represents Transformation Grammar view and distinguishes transformations of PUs and lexical variation. Here we consider only lexical and semantic deviations which are called lexical variation according to the abovementioned linguist. The linguist as serts that numbers of PUs can take lexical variations in comparison with their base form. Except that, some PUs are more fixed than others, and some, for example, to take place and at all, do not vary at all; however variation is very widespread [6,p.120]. Verb variation is the commonest type and points clearly to instability in the forms of PUs, however, it is not a uniform phenomenon. While in many cases the meaning of the whole is barely affected by variation, other variations reflect important syntactico-semantic distinctions. [6, p.124]. The following examples show verb variation without change in meaning. Regis ter difference is sometimes possible though. In some cases the verbs which alternate each other reflect hyponym distinction.

(1) to cook someone's goose $\rightarrow$ to do something that spoils someone's plans and prevents them from succeeding [11]:

"The position I had in mind would require a NUT-2, but we could probably make an exception."

"Ah," I replied, surprised yet somewhat relieved that Phoebe Smalls had also overcooked the goose in the ins anity department. "Has the entry requirement been changed since Victor was heading up the department?" [Fforde, 2012].

The alternating verbs may not be synonymous in other contexts

(2) to give somebody/something the green light $\rightarrow$ to give permis sion for someone to do something or for something to happen [8]:

"... I want Iago in my office in ten minutes."

"He's doing that spinoff with Hamlet," said Mr. Fainset from across the room.

"Iago v. Hamlet? They got the green light for that?"

"Shylock bankrolled their appeal and got Portia to represent them..." [Fforde, 2011].

The copula to be alternates with other verbs, however inverse cases occur when a verb is alternated by to $b e$.

(3) to be in (a bitof) a jam $\rightarrow$ to be in a difficult situation [10].

Although we never really saw eye to eye with the local police force when we were SpecOps, we always used to help them out if they got into a jam, and the young ones never forgot it. Hard not to, really, when some lunatic plucks you from the jaws of a werewolf or something [Fforde, 2007].

The linguist as serts herself that, "in most of such cases the PUs are better analyzed as adjectival groups or adjuncts" [6, p.125]. The cases of varying nouns are broadly synonymous:

(4) as luck would have it $\rightarrow$ by good or bad luck [8]:

Apart from one other person I had the breakfast room all to myself. As fate would have it, that one other person was Colonel Phelps [Fforde, 2002].

Quite often the variation may take the form of singular or plural forms of the same noun or male or female noun equivalents:

(5) to have more than one string to one's bow $\rightarrow$ have another interest or skill that you can use if your main one can't be used [11]:
"That's your best advice? Perjure myself?"

Snell coughed politely.

"The astute lawyer has many strings to his bow, Miss Next. They've got Mrs. Fairfax and Grace Poole to testify against you. It doesn't look great, but no case is lost until it's lost. They said I couldn't get Henry V off the war crimes rap when he ordered the French POW s murdered, but I managed it - ... [Fforde, 2003].

Variant nouns sometimes reflect eithergeneral or specific distinctions as well as their variation may be represented with a hyponym or meronym:

(6) to catch someone's eye $\rightarrow$ to establish eye contact with someone [10]:

His voice sounded the same. The warmth and sensitivity I had once known so well were still there. I looked up at him, caught his gaze and looked away quickly. I had felt my eyes moisten [Fforde, 2002].

There are many cases where the nouns are not synonymous outside the PU and may even belong to different semantic fields:

(7) quicker than you can say Jack Robinson $\rightarrow$ almost immediately [11]:

"I don't often take apprentices,"s he carried on, disregarding me completely, "but they were going to allocate you to the Red Queen... Half of all she says is nonsense and the other half is irrelevant. Mrs. Nakajima recommended you most highly, but she has been wrong before; cause any trouble and I'll bounce you out of Juris fiction quicker than you can say ketchup. How are you at tying shoelaces?" [Fforde, 2003].

In metaphoricalPUs the nouns often appear to be the focus of the metaphor. In such cases variations do not have changed meanings but mental images of the metaphor may differ considerably. The distinctions are therefore greater than those between many verb variations.

Adjective and modifier variation. As well as in previous cases adjective variation is broadly synonymous.

Sometimes alternated adjectives may have quite different meanings in other PUs or collocations.

(8) to catch somebody red-handed $\rightarrow$ to discover someone doing something illegal or wrong [11]:

"We've been following Byron2 for a month, but he's smart. None of the forged scraps of 'Heaven and Earth' can be traced back to him."

"Wiretap?"

"We tried, but the judge said that even though Byron2's surgery to make his footclubbed in an attempt to emulate his hero was undeniably strange, and then getting his half-sister pregnant was plainly disgusting, those acts only showed a fevered Byronic mind, and not necessarily one of intent to forge. We have to catch himinky-fingered, but at the moment he's off on a tour of the Mediterranean. We're going to attempt to get a s earch warrant while he's away" [Fforde, 2003].

Particle variation. Variation of a prepositional or adverbial particle involves no apparent shift in meaning because the variations from/out of and round/around are entirely conventional. Other variations, however, may reflect a shift in focus.

(9) in the back of someone's mind $\rightarrow$ remembered by someone, but not very important [11]:

If I had understood it correctly, the asteroid wouldn't hit if we didn't think it would. The trouble was, we thought very much that it would.... I pushed these thoughts to the back of my mind and headed toward the stage, where I could see 
Landen standing at the side with Tuesday, chewing her nails [Fforde, 2012].

In linguistic literature conjunction variation is mentioned but this type of variation is not characteristic for J. Fforde's phraseological deviations as well as for his individuallyauthor's picture of the world. It should be mentioned that there are cases of PUs where the variation consis ts broadly of some inserted or suppressed material. Such variations are called specificity and amplification [6]. One version is simply a fuller version of the other, adding emphasis or precision. It should be mentioned that variations which are fixed in dictionaries are mentioned here. The extra data in most cases is adjectival or adverbial. Occasionally there is catenated verb or expanded or augmented nominal group.

(10) to stop (dead) in your tracks $\rightarrow$ to suddenly stop moving or doing something [11]:

The manager punched in a long series of numbers, and then Friday punched an even longer series of numbers. There was a shift in the light to a greeny blue, the manager and all the customers stopped dead in their tracks as time ground to a halt, and a faint buzz replaced the happy murmur of shoppers [Fforde, 2007].

Truncation. Amplification and truncation are two sides of the same coin, but in the majority of cases, are attested as original forms. Many are traditional proverbs and sayings, downgraded from their canonical forms to lower-level grammatical units - a compound sentence to a single clause or a clause to a group. Quite often the reduced forms can be seen in terms of ellipsis, since in many cases an allusion to the original and fuller form remains. In most cases the truncated forms themselves have variations but sometimes the original fuller form has almost dis appeared from the lexicon.

(11) to think twice before doing something $\rightarrow$ to consider carefully whether one should do something [11]:

There was a strange and pregnant pause. The danger was real and very clear, and even seasoned PROs like Bradshaw and Havisham were thinking twice about entering Perkins' lab [Fforde, 2004].

Reversals. Phraseological reversals are not characteristic for J. Fforde's phraseological deviations as well as for his individually-author's picture of the world. This type of variation has no meaning distinction here.

(12) in the right place at the righttime $\rightarrow$ in the best position to take advantage of an opportunity [9]:
"Then," replied my father, "we will have to outsmart them! They will expect us to arrive at the right time and the right place - but we won't. We'll arrive at the right place but at the wrong time, then simply wait. Worth a try, wouldn't you say?"

I smiled. "Definitely!" [Fforde, 2003].

Register variation Variations often reflect distinctions in formality. In this type of variation variant words, more or less synonymous in general meaning, belong to different registers but the first variation is more formal than the second.

(13) to be no bed of roses $\rightarrow$ to be difficult or unpleas ant [9]:

"If promising meant killing you," I replied in an exasperated tone, "I wouldn't have gone along with it!"

"SpecOps-17 work ain't no bed of roses, Thursday. I've had enough, and believe me, having this little nurk coiled up in my head is not as easy as it looks [Fforde, 2003].

Conclusions and prospects for further research. Dealing with postmodernist discourse of J. Fforde we should admit that the novels sound not only hilarious and original, but also confusing to follow and conceptually difficult. It portrays a fictional reality quite radically with our normal world. Ontological differences between fact and fiction are also very perplexing; it makes a reader to exert oneself to continue reading and to get used to moving from the actual text world to the text worlds. Considering phraseological variations in postmodernist discourse, compared to PUs' base forms which are dictionary forms in particular we can as sert that PU variations are not rarity in there, though they make approximately $10 \%$ of the whole selection. These examples of deviations s of PUs indicate not only author's diverse individual style but also flexibility of semantics and structure of PUs to satisfy the intended contextual effects. The abovementioned examples of deviations highlight Jasper Fforde's individual and peculiar worldview which is implemented and demonstrated in the literary worlds created by the author. PUs play an important role in imaginary worlds creation and they can take forms that differ from their base forms: constituents of PUs can be varied as well as their register and form. At the same time the role of context is very important when creating the modified semantics of the constituents of PUs of English literary discourse. Only with the help of context and extra linguistic factors it is possible to estimate the peculiarity of phraseological variations in postmodernist discourse. The nature of variations of PUs in English postmodernist text is systematical. Our further research will be devoted to functions of PUs in postmodernist discourse.

\section{REFERENCES}

1. Bekhta ,Ivan A. Dyskurs naratora v anhlomovnij prozi. Kyiv, 7. Naciscione, Anita. Phraseological units in discourse: towards apUkraine: Hramota, 2004.

2. Bekhta, Natalya "Suchasni koncepciyi naratyvu: netypova opovid" Inozemna filolohiya. Ukrayins"kyj naukovyj zbirnyk 123 (2011): 287-300.

3. Burger, H.and Buhofer, A.and Sialm, A. Handbuchder Phraseologie. Berlin, Germany: de Gruyter. 1982. Print.

4. Currie, Mark. Postmodern Narrative Theory. NY, USA: Palgrave, 1998.

5. Fraser, Bruce. "Idioms within a transformational grammar" Foundations of Language 6 (1970): 22- 42. Print.

6. Moon, Rosamund. Fixed expressions andidioms in English: a corpus-based approach: [Oxford studies in lexicography, and lexicology]. Oxford, GB: Clarendon Press, 1998.

plied stylistics. Riga, Latvia: Lat vian Academy of Culture, 2001.

8. N.p. Cambridge Dictionaries online. Cambridge University Press, n.d. Web. 20 June 2017.

9. Cowie, A.P., Mackin, R.\& McCaig, I.R. Oxford Dictionary of English Idioms. Oxford: Oxford University Press, 2007.

10. Siefring Judith The Oxford Dictionary of Idioms. Oxford University Press, 2004.

11. N.p. The Free Dictionary by Farlex Farlex, Inc, n.d. Web.12 July 2017.

\section{Девиации фразеологических единиц в индивидуально-авторской картине мира}

\section{Н. Д. Негрич}

Аннотация. Статья посвящена идиомам английскогоязыка в индивидуально-авторской картине мира в романах британского писателя постмодер нистской литературы - Джаспера Ффорде. Языковая картина мираотражает и интерпретиру ет реальность с помощью языковых средств, фразеологические единицы занимают важное место среди них. Сознание автора неизбежно связано с индивидуально-авторской картиной мира. Индивидуально-авторская картина мира - это фрагмент языковой картины мира с позиции авторского мировоззрения, мировосприятия и понимания мира. 